\title{
The possible protective effect of Gardenia Jasminoides extracts on the dentate gyrus changes in an Alzheimer-induced model in adult male albino rats : Histological and Immunohistochemical study
} Original

Article

\author{
Maha Abo Gazia
}

Department of Histology, Faculty of Medicine, Kafr-Elsheikh University

\begin{abstract}
Introduction: Alzheimer's disease $(\mathrm{AD})$ is the most common diagnosed form of senile dementias, a neurodegenerative disease resulting in cognitive impairment in the elderly. Geniposide, a component extracted from the fruit of Gardenia Jasminoides, is the widely used herb for treatment of brain diseases and reduce amyloid plaques deposition which is an intricate process in $\mathrm{AD}$.

Aim of the work: This study aimed to demonstrate the histological changes in the dentate gyrus of hippocampus in an Alzheimer-induced model and the possible neuroprotective effect of Gardenia Jasminoides extract.

Materials and methods: Thirty six adult male albino rats(4-6 months) ,weighing about 180-200g were equally divided into three groups. Group I was the control group, group II (Alzheimer-induced model group) was given aluminum chloride dissolved in distilled water, $(300 \mathrm{mg} / \mathrm{kg} / \mathrm{day})$ orally for one month. Group (III) (Geniposide-treated group) was given Geniposide dissolved in distilled water,at a dose of $(100 \mathrm{mg} / \mathrm{kg} /$ day $)$ orally concomitant with aluminum chloride at the same dose and for the same period of the previous group. Cognitive functions were assessed by the passive avoidance test. At the end of experiment, temporal lobes of cerebral cortex were removed, fixed and processed for H\&E and congo red stains. Immunohistochemical study was performed for detection of Glial fibrillary acidic protein (GFAP) and inducible nitric oxide synthase (INOS). As tau protein can be phosphorylated by glycogen synthase Kinase-3 $\beta(\mathrm{GSK}-3 \beta)$. Western blot assay to investigate the total protein expression level of glycogen synthase Kinase-3 $\beta($ GSK-3 $\beta$ ) was performed. Comet assay was used to detect any DNA damage.

Results: Alzheimer-induced model group showed significantly impaired cognitive performance which was improved after treatment with Geniposide extract. Aluminum chloride induced changes in the dentate gyrus in the form of apparent increase in immature neurons, disturbed granular cell layer and distortion of pyramidal cells that appeared with darkly stained pyknotic nuclei. Intense positive immunoreaction for GFAP in the cytoplasm and processes of astrocytes were also observed. The ultra structural study exhibited neurons with apoptotic features, heterochromatic nuclei and their cytoplasm contained dilated cisternae of rough endoplasmic reticulum. Gardenia Jasminoides extracts administration ameliorated these histological alterations.

Conclusion: Administration of Gardenia Jasminoides extracts significantly ameliorated the neuro- degenerative alterations induced in the Alzheimer model. So, daily supplements of Gardenia Jasminoides extracts might be of benefit for the elderly people at risk of developing AD.
\end{abstract}

Received: 31 December 2018, Accepted: 28 January 2019

Key Words: Aluminum, alzheimer, chloride, gardenia, jasminoides, .

Corresponding Author: Maha Abo Gazia, PhD, Histology Department, Faculty of Medicine, Khafrelskeikh University, Khafrelskeikh, Egypt, Tel.: +20 1228663099 E-mail: mahaabogazia@yahoo.com

ISSN: 1110-0559, Vol. 42, No. 2

\section{INTRODUCTION}

Alzheimer's disease (AD) is the most prevalent neurodegenerative disorder in elderly, characterized by progressive cognitive impairment and memory loss and other symptoms of dementia ${ }^{[1]}$, with clinical signs as inability to learn, loss of language function, delusions and other manifestations that affect the patient's ability to perform activities of daily life ${ }^{[2]}$. Several studies have used aluminum to induce an animal model of neurotoxicity and Alzheimer disease $^{[3]}$.
This disease has been reported in most of clinical cases of senile dementia which included deposition of senile plaques, lesions of cholinergic neurons and synaptic alterations in cerebral cortex, hippocampus and other brain regions ${ }^{[4]}$. The multiple factors involved in the progress of $\mathrm{AD}$ are apoptosis, oxidative stress inflammatory response, mitochondrial dysfunction and disturbance of energy metabolism homeostasis. The severe loss of function of the cholinergic neurons associating with dementia in $\mathrm{AD}$ is still not clearly understood ${ }^{[5]}$. An inflammatory mediator as nitric oxide (NO) is part of pathogenesis of 
Alzheimer's and is generated by nitric oxide synthase (NOS). Three isoforms of NOS have been identified in the brain, neuronal NOS (nNOS), and endothelial (eNOS) as constitutive enzymes and the hardly expressed inducible enzyme (INOS). Significant increase in the expression of these NOS isoforms were reported in aged hippocampus and apparently expressed in $\mathrm{AD}$, indicating increase in the levels of $\mathrm{NO}$ in brain in neurodegenerative disorders and proved that NO was involved in the pathology of these diseases by different mechanisms and could be one of the free radicals produced in Alzheimer's ${ }^{[6,7]}$.

It has been explained that Aluminum administration results in neurodegenerative effects on hippocampus and is considered a potent neurotoxin associated with $\mathrm{AD}$ causality disease ${ }^{[8,9]}$.

Geniposide, a component extracted from the fruit of Gardenia jasminoides is considered to be responsible for any effects of the herbs and genipin is its glycon. Gardenia fruits have been used as a treatment herbal medicine for the treatment of hepatic disease, inflammatory disease, contusions and brain disorders ${ }^{[10,11]}$. Previous studies have focused on the neuroprotective effect of geniposide in brain disorders, particularly, neurodegenerative diseases. Its effects to improve learning memory ability and the normalization of objection recognition has been shown previously in experiment of animal behavior ${ }^{[2,13]}$.

The hippocampus in the brains of human is a part of the limbic system and concerned with cognition and memory consolidation, the humans and mammals have two hippocampi which are closely related to the cerebral cortex and contain two main components, Ammon's horn and the dentate gyrus. It was reported that the dentate gyrus contribute to the formation of the new memories and one of the important areas of the brain where neurogenesis take place ${ }^{[14]}$. The hippocampus has been reported to be susceptible to neurotoxic harm and in cases of $\mathrm{AD}$ it is one of the first regions of the brain to be affected causing memory loss and disorientation ${ }^{[15]}$.

The present work was aimed to study the possible protective effect of Gardenia Jasminoides extracts on the histological alterations induced in the dentate gyrus in an animal model of Alzheimer disease.

\section{MATERIALS AND METHODS}

The experimental protocol was approved by the institutional Ethics Committee (Faculty of Medicine, Cairo University).Animal housing and brain samples from the experimental animals were performed at Kasr Al Ainy Faculty of Medicine, Cairo University . Thirty six adult male albino rats (4-6 months) weighing about 180-200g were used in this study. The rats were housed in clean properly ventilated cages under similar conditions under and had free access to rat standard laboratory diet and water throughout the experiment. The rats were equally divided into three groups:

- Group I (Control group): included 12 rats.
- Group II (Alzheimer-induced model group): included 12 rats that were given aluminum chloride powder (CAS No. 7446-70-0, Sigma Aldrich Co., Egypt) dissolved in distilled water, which was given orally at a dose of $(300 \mathrm{mg} / \mathrm{kg} / \mathrm{day})$ for one month $^{[16]}$

- Group III (Geniposide-treated group): included 12 rats that were treated with geniposide powder (CAS No. 24512-63-8, Sigma Aldrich Co., Louis, Missouri, USA) dissolved in distilled water which was given orally at dose of $(100 \mathrm{mg} / \mathrm{kg} / \text { day })^{[17]}$ concomitantly with aluminum chloride daily for one month.

\section{Learning and memory tests}

Passive avoidance test

This test is generally considered as a measure of long-term memory, and it was performed according to methods that was previously described(18). An illuminated compartment (floor side; $15.5 \times 10 \mathrm{~cm}$, base side; $15.5 \times 4.5$ $\mathrm{cm}$, height $8.5 \mathrm{~cm}, 20 \mathrm{~W}$ ) connected to a dark compartment (floor side; $15.5 \times 10 \mathrm{~cm}$, base side; $15.5 \times 4.5 \mathrm{~cm}$, height 8.5 $\mathrm{cm}$ ) by means of a guillotine door. On habituation day, the rat was set in the illuminated compartment and allowed to explore freely for 30 seconds, then the door was raised and once the rat get in the dark compartment with four paws, the door was closed and the latency to enter was recorded from the time the door was closed. On the next day, one learning trial was presented by repeating the steps of the habituation trial and 3 seconds after the door was lifted, an unavoidable scrambled electric foot shock $(0.5 \mathrm{~mA}$ for $2 \mathrm{~s}$ ) was transmitted through the grid floor of the dark compartment then the rat was removed 30 seconds later to its home cage. Retention of the passive avoidance response (task) was tested $24 \mathrm{~h}$ later by positioning the animal on the illuminated compartment and recording the latency in reentering the dark compartment; increased escape latency to dark compartment is a good index of long-term memory ${ }^{[18]}$.

\section{Histological study}

At the end of the experiment, all rats were sacrificed after ether inhalation. In order to harden the brain during its sectioning, intracranial perfusion fixation was performed. The animals skull vaults were dissected out and temporal lobes were divided sagittally, fixed in bouin's solution immediately for preparation of paraffin blocks and sectioned at $5 \mu \mathrm{m}$ thickness for histological stain (H\&E) and congo red stain (for amyloid plaques deposits) ${ }^{[19]}$.

For immunohistochemical study of Glial Fibrillary Acidic Protein (GFAP) in astrocytes and inducible nitric oxide synthase (INOS) marker in the granular cell, $5 \mu \mathrm{m}$ thick sections were deparafinized in xylene. Rehydrated sections were incubated with $3 \%$ hydrogen peroxide in humidified boxes to block endogenous peroxidases activity. Microwave assisted antigen retrieval was performed for $20 \mathrm{mim}$. Some sections were incubated overnight at $4 \mathrm{oC}$ with primary antibody Polyclonal rabbit anti-rat, anti-INOS 
primary antibody for (transduction laboratories,USA), and the other sections with anti-GFAP primary antibody for (AM020-5M Bio-Genex) diluted 1:1000 overnight at $40 C$. Sections were washed and incubated in biotinylated goat anti-rabbit secondary antibody after washing, the sections were incubated with peroxidase-linked ABC (Vector laboratories Burlingame, California, USA) for 90 min. The slides were counter stained with hematoxylin. Positive reaction for iNOS appeared as cytoplasmic brown accumulation in the granular cells, where the positive reaction for GFAP was visualized as brownish cytoplasmic granules inside astrocytes.

Negative controls were prepared using the same steps except that PBS was applied instead of the primary antibodies $^{[20]}$.

\section{Morphometric study}

(a) The area percentage of GFAP expression in the astrocytes in GFAP immunohistochemically stained sections was performed in different study groups. (b) The area percentage of INOS expression in the granular cell layer in INOS immunohistochemically stained sections was also performed in different study groups. All the measurements were performed using a magnification of 400x and were carried out in 10 fields in each of five different sections taken from five different rats of each group.

All measurements were taken using the image analyzer Leica Qwin V. 3 (Leica, Wetzlar, Germany) computer system.

\section{Western blot assay}

Fifty milligrams of tissue from the temporal lobe of rat brain per animal was suspended in homogenization buffer containing Tris-Hcl 50mM (pH: 7.4), 2mM/EDTA, $10 \mathrm{mM} \beta$-glycerol phosphate, $10 \mathrm{mM} \mathrm{NaF}, 1 \mathrm{mM}$ PMSF and complete protease inhibitor cocktail using polytron homogenizer in ice and then centrifuged at $12.000 \mathrm{Xg}$ for 5 minutes at $4 \mathrm{oC}$. Before taking the supernatants on ice, protein contents were determined using Bio-Rad Protein Assay Kit. Samples were then added with loading buffer to the same concentration. Briefly, samples containing equivalent amounts of $50 \mu \mathrm{g}$ of total protein were loaded onto SDS-PAGE gel using the Bio-Rad minigel system and then transferred to PVDF membrane (Bio-Rad, Hercules, CA, USA) by electrophoresis. At room temperature, the blots were blocked with $3 \%$ non fat dry milk in trisbuffered saline with tween (TBST). Blotting membranes were probed overnight with specific primary antibodies [rabbit polyclonal GSK3- $\beta$ (PS-9), 1: 1000, Cell Signaling technology Inc, Danvers, MA, USA; GSK3- $\beta$ (PY-216), Abcam, 1:1000; GSK3- $\beta$ (Total), Abcam, 1:1000; mouse monoclonal $\beta$-actin, Abcam, $0.5 \mu \mathrm{g} / \mathrm{ml}$. Membranes were washed 3 times with $0.1 \%$ Tween and TBST. Then labeled with secondary antibodies (goat-anti-rabbit IgGH\&L (horseradish peroxidase, HRP), Abcam, 1:20000; and goat-anti-mouse IgG-H\&L (HRP), Abcam, 1:20000 respectively. Finally immunoreactive protein bands were visualized with an enhanced chemiluminescence reagent (ECL, Pierce, Rockford, IL, USA) and Alliance Gel-doc (Alliance 4.7 Gel doc, UV tec UK). UV tec software (UK) was used to semiquantify the density of each individual protein band. Band densities were normalized for protein loading, using $\beta$-actin as a loading control ${ }^{[21]}$.

\section{Comet assay}

Determination of DNA degeneration in hippocampus tissue of AD-induced model was carried out in biochemistry department, Cairo University. Comet assay was used to detect any prospective damage for DNA after various treatments. It detects DNA strand breaks and alkali labile sites by measuring the migration of DNA from immobilized nuclear $\mathrm{DNA}^{[22]}$. Cells from control and experimental groups were dispersed and immobilized in an agarose gel on microscope slides. Following electrophoresis, the slides were rinsed in neutral buffer and the gel with its contents were fixed using ethanol. The DNA in the fixed slides was stained with the fluorescent DNA-specific stain Gel Red. Stained slides were examined using a fluorescent microscope. The migration of DNA away from the nucleus, i.e. comet tail length, was measured by image analysis software which determined various parameters of the comet, i.e. tail length, percentage of DNA in tail, tail moment $=\%$ DNA in tail $\mathrm{X}$ tail length (Figure A ).
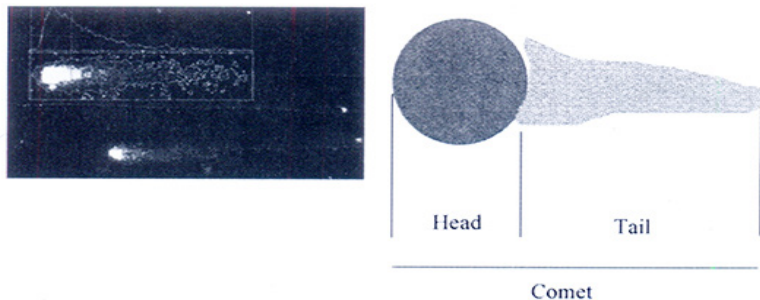

Fig. A: A diagram of typical comet showing distribution of DNA in tail and head.

In the current study, the comet assay was performed according to the protocol described by (Singh et al., 1988). Comet 5 image analysis software developed by Kinetic Imaging, Ltd. (Liverpool, UK) linked to a CCD camera was used to assess the quantitive and qualitative extent of DNA damage in the cells by measuring the length of DNA migration, the percentage of migrated DNA, and finally, the tail moment. Generally, 50 to 100 randomly selected cells were analyzed per sample ${ }^{[22]}$.

\section{Statistical analysis}

Statistical analysis of the results of morphometry was performed using the statistical package for the social sciences (SPSS; SPSS Inc., Chicago, Illinois, USA) software. Comparison between groups was made using one way analysis of variance (ANOVA), followed with Tukey multiple comparisons post-hoc test. Data were expressed as mean + S.D., $P$ value of 0.05 or less was considered statistically significant. 


\section{RESULTS}

\section{Effect of AD and Geniposide on cognitive functions}

Results indicate that Alzheimer disease induced deficiency in learning and locative memory in rats during the passive avoidance test. Alzheimer-induced model group compared to the control group and Geniposidetreated group exhibited a significant decrease in the escape latency to the dark compartment in the passive avoidance test (Fig. B) $\quad(p<0.05)$.

\section{Histological results}

\section{Group I (Control group)}

Examination of H\&E stained sections of the brain temporal lobe revealed the hippocampus with pair of C-shaped components: Ammon's horn and the dentate gyrus (Figure 1). The layers of the dentate gyrus were the molecular, granular and polymorphic layers. The granular layer was the most prominent and composed of closely packed granular cells with rounded vesicular nuclei. The polymorphic layer composed of many types of cells, including pyramidal neurons which appeared as large cells with long processes, microglial and astrocytes cells (Figure 2). The granular cell layer of the dentate gyrus appeared with rounded pale vesicular nuclei and immature neurons with oval dark nuclei in the sub granular zone in Congo red stained sections (Figure 3). Examination of INOS immunostained sections revealed slightly positive cytoplasmic reaction in the granular cell layer of the dentate gyrus (Figure 4). GFAP Immunostained sections showed positive cytoplasmic reaction in the form of dark brown granules in astrocytes and their processes (Figure 5).

\section{Group II (The Alzheimer-induced model group)}

Examination of $\mathrm{H}$ \& $\mathrm{E}$ stained sections showed a shrunken dentate gyrus and dilated congested blood capillaries (Figure 6) and distortion of the granular cells. Many cells of the granular layers appeared with a pale vacuolated cytoplasm with apparent increased in immature neurons (Figure $7 \mathrm{a}, \mathrm{b}$ ). The cells of polymorphic layer showed disturbed arrangement and apparent decrease in pyramidal cells had a darkly stained pyknotic nuclei (Figure 8 a,b). Examination of Congo red stained sections showed amyloid deposition with orange coloration in the granular layer with dilated congested blood capillaries and large vacuolated cells with darkly stained pyknotic nuclei (Figure 9). Deposition of amyloid in the polymorphic layer with increased number of immature cells (Figure 10). Immunostaining using INOS antibody showed increased staining intensity in the cells of the granular layer of the dentate gyrus (Figure 11). In addition immunostaining using GFAP antibody revealed apparent increase in intensity of glial fibrillary acidic protein in all layers of the dentate gyrus compared to the control group. Furthermore, the astrocytes were apparently increased in number and larger in size with longer processes (Figure 12).

\section{Group III (Geniposide-treated group)}

$H \&$ E stained sections of this group showed more or less restoration of the structure of the dentate gyrus compared to that of the control group (Figure 13). The Congo red stained sections revealed granular cell layer of the dentate gyrus which similar to those of the control group (Figure 14). The immunohistochemical staining using INOS antibody showed reduction in the immune reaction in the granular cells of the dentate gyrus compared to group II (Figure 15). Examination of GFAP antibody stained sections revealed an apparent decrease in the number of GFAP-immunoreactive astrocytes compared to group II (Alzheimer-induced model group) (Figure 16).

\section{Morphometric results}

Evaluation of the obtained data of area percentage of GFAP and INOS immunoreactivity showed a statistically significant increase in the AD-induced model group compared with the other two groups. The group treated with geniposide showed a significant increase in immunoreactivity for GFAP and INOS antibodies compared with the control group and significant decrease compared with the AD induced model group (Table 1).

\section{Western blot assay}

Total protein expression of GSK3 $\beta$ in Hippocampus did-not differ significantly among the different groups. The data were presented as the ratio of total GSK $3 \beta / \mathrm{B}$-actin, $1.325+0.082$ for control group, $1.294+0.059$ for the $\mathrm{AD}$ group, $1.294+0.080$ for the geniposide group (Figure C).

For assessment of the functional state of GSK3 $\beta$, probed the phosphor-GSK3 $\beta$ at different phosphorylation sites, specifically S9 and Y216 by specific antibodies revealed that aluminium chloride treatment ( $\mathrm{AD}$ group) elevated the active form GSK3 $\beta$ (pY216) (pY-216/ $\beta$-actin: $1.293+0.091)$ but suppressed the inactive form GSK3 $\beta$ (pS9) (pS9/ $\beta$-actin: $0.838+0.019) \quad(P<0.01) \quad$ (Figure). However, geniposide attenuated the activation of GSK3 $\beta$ in $\mathrm{AD}$ group. Rats treated with geniposide showed decrease in the level of GSK3 $\beta$ (pY216) by about $25 \%$ (pY-216/ $\beta$ actin: $0.871+0.087$ ) but increased the level of GSK3 $\beta$ (pS9) by about $20 \%(\mathrm{pS}-9 / \beta$-actin: $1.179+0.056)$ compared with the AD group $(P<0.01)$ (Figure $\mathrm{C}$ ).

\section{DNA degeneration in Hippocampus tissue with Comet assay}

(Table 2) and (Figure17) show that DNA damage was significantly increased in Alzheimer-induced model group $(\mathrm{B}, \mathrm{C})(P<0.05)$ that was indicated by increase in tail length, tail DNA \% and tail moment compared to normal control (A). This increased DNA damage was reduced after administration of geniposide (D). 


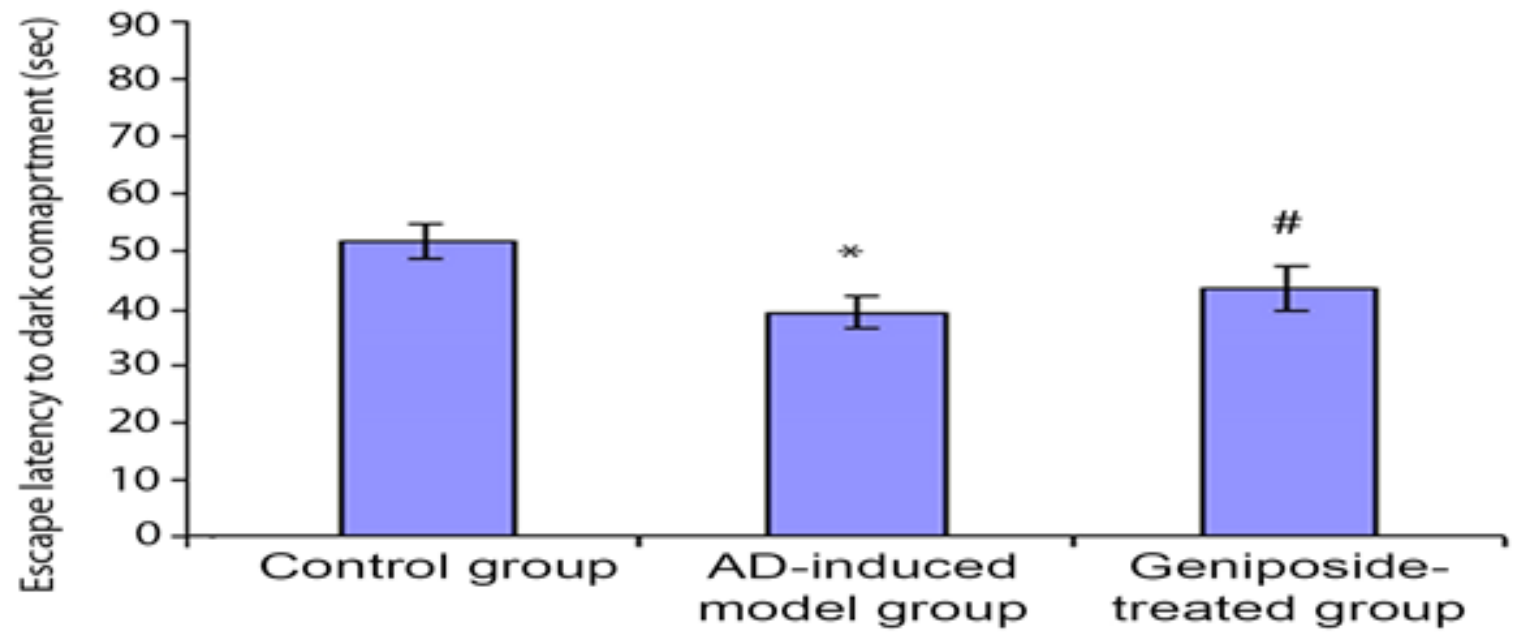

Fig. B: Escape latency recorded during passive avoidance test. Latency to enter the dark compartment in Alzheimer-induced model group compared to control group.*: significant compared to control group, \#: significant compared to Geniposide-treated group, at $p<0.05$.

A GSK3

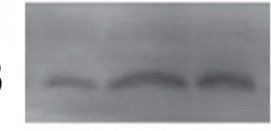

pY216

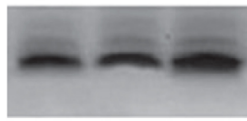

pS9

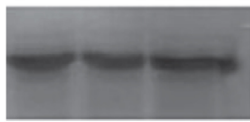

total

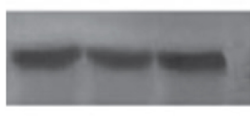

$\beta$-Actin

Control AD Geni
C

WB: GSK3 $\beta$ (pY216)

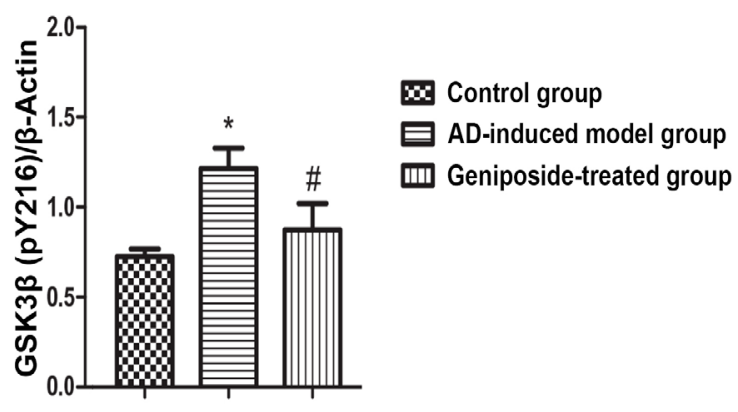

B

WB: GSK3 $\beta$ (total)

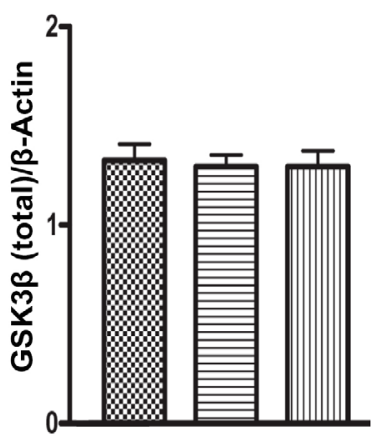

D.. Control group

$\square$ AD-induced model group

س Geniposide-treated group
D

WB: GSK3B (pS9)

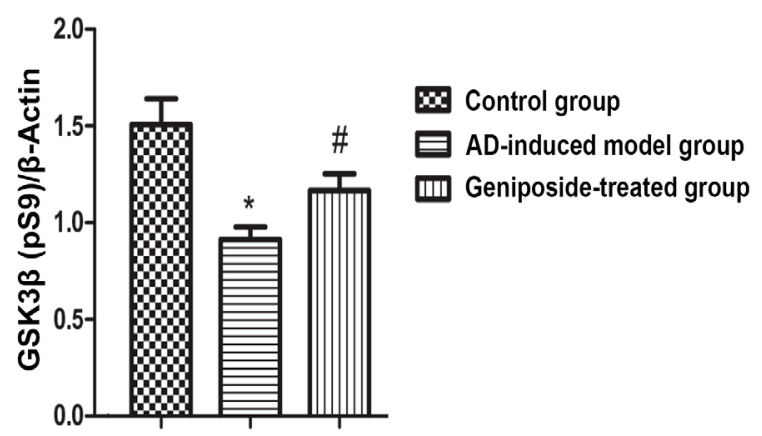

Fig. C: Western blot assay of GSK3 $\beta$ at different phosphorylation sites in response to AD, and geniposide treatment was shown in A. Total GSK3 $\beta$ protein was shown in the histograms of brain cortex (B). Quantitative analysis shows that no significant difference on the total expression of GSK3 $\beta$ among the groups (B).Phospho-GSK3 $\beta$ (inactive) and (active) was presented as the ratio over loading control ( $\beta$-Actin). AD-induced model group significantly elevated GSK3 $\beta$ activity compared with control group as reflected with increased pGSK3 $\beta Y 216(\mathrm{C}$, *, compared with control, $P<0.01)$ and decreased pGSK3 $\beta$ S9 $(\mathrm{D}, *$, compared with control, $P<0.01)$. Geniposide-treated group prevented AD-induced model group increase in GSK $3 \beta$ activity, reflected as lower ratio of pGSK3 $\beta Y 216(\mathrm{C}$, \#, compared to AD group, $P<0.01)$ and higher ratio of pGSK3 $\beta S 9$ (D, \# compared to AD group, $P<0.01$ ). 


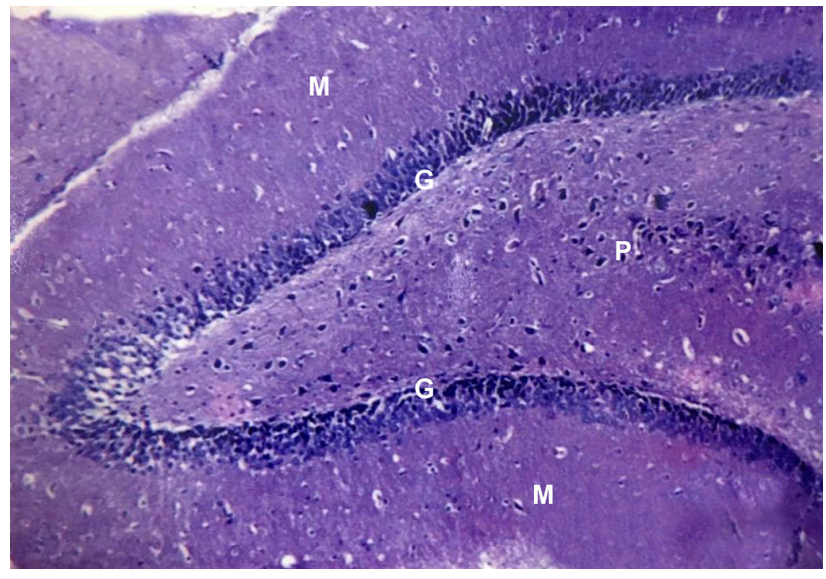

Fig. 1: The hippocampus showing the dentate gyrus consisting of a granular cell layer $(\mathrm{G})$, a molecular layer $(\mathrm{M})$, and a polymorphic layer (P). (Control group, H\&E, $\times 200)$

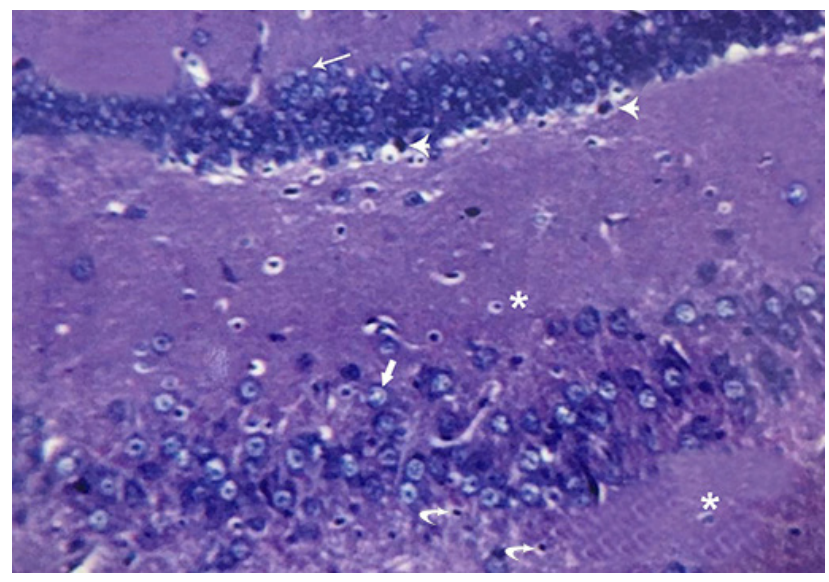

Fig. 2: The granular cell layer containing granular cells with vesicular nuclei $(\rightarrow)$ and immature neurons with oval darkly stained nuclei $(\rightarrow)$. The polymorphic layer containing pyramidal cells (thick arrow), astrocytes (Curved arrow), and microglia $(*)$. (Control group, H\&E, $\times 400)$

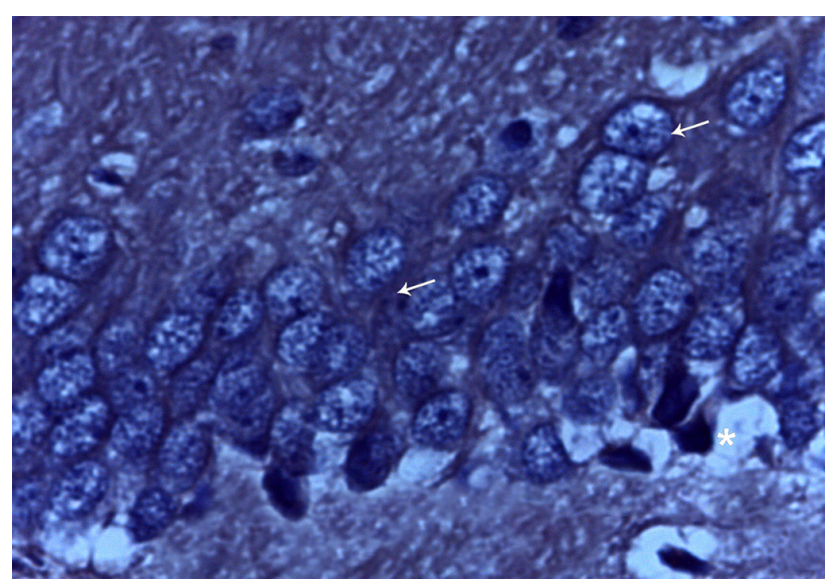

Fig. 3: The granular cell layer of the dentate gyrus. Granular cells appear with rounded pale vesicular nuclei $(\rightarrow)$ and immature neurons with oval dark nuclei $(*)$ in the sub granular zone. (Control group, Congo red, $\times$ 1000)

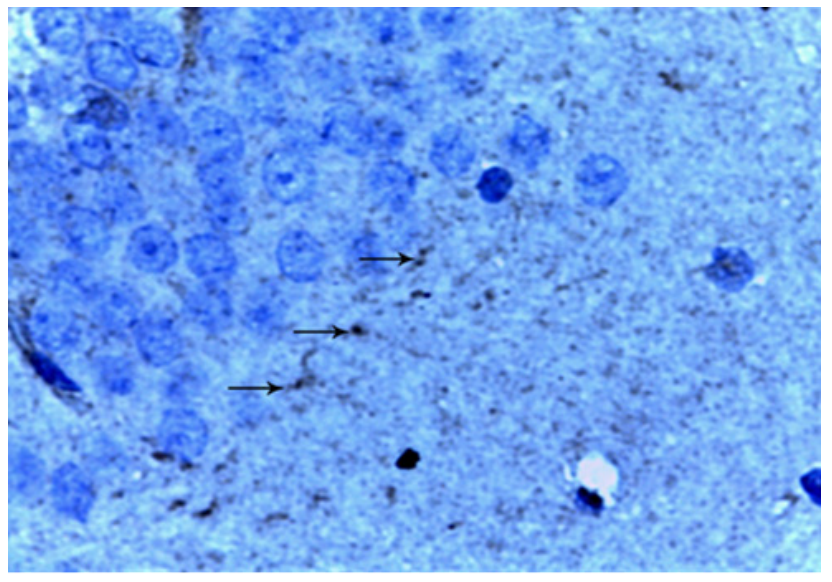

Fig. 4: showed Slight cytoplasmic immunoreactivity for INOS antibody localized to the granular cell layer of the dentate gyrus. (Control group, immunoperoxidase staining, $\times 1000$ )

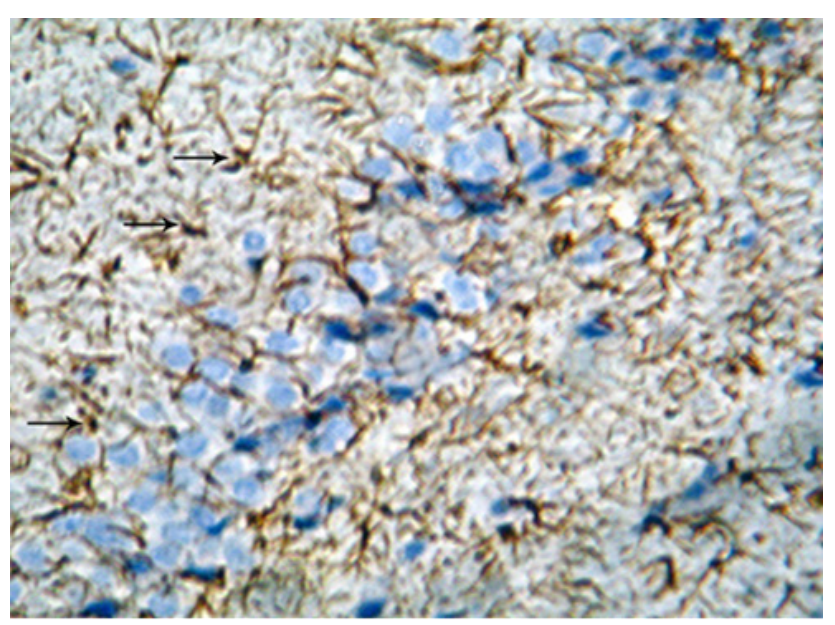

Fig. 5: showed positive GFAP immunoreactivity in the cytoplasm of astrocyte and their processes in the form of dark brown granules. (Control group, immunoperoxidase staining, $\times$ 400)

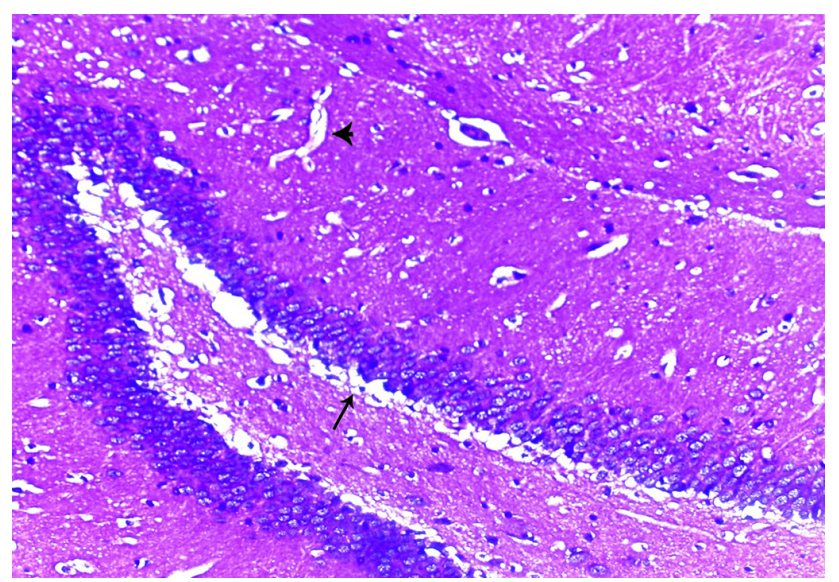

Fig. 6: Showing shrunken dentate gyrus and distortion of the granular cell layer $(\rightarrow)$. Notice dilated congested blood capillaries $(\rightarrow)$. (Alzheimer model group, $\mathrm{H} \& \mathrm{E}, \times 200$ ) 


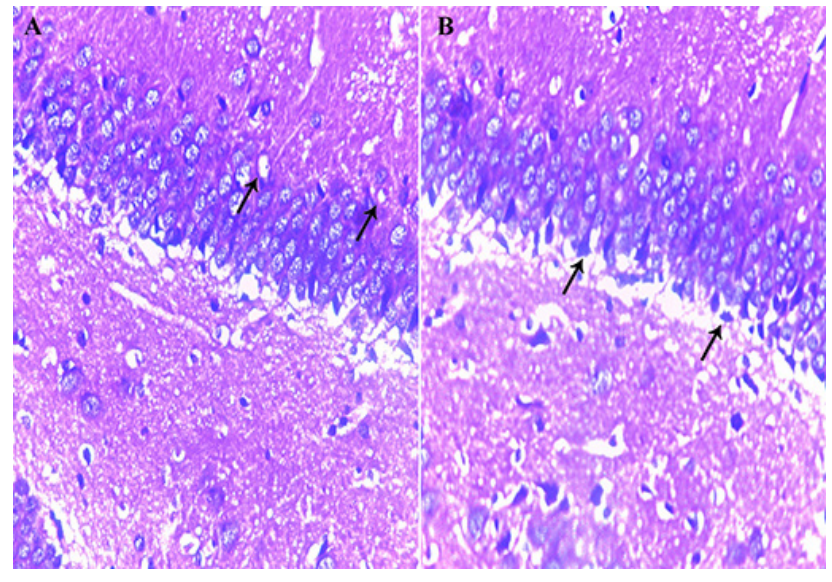

Fig. 7: (A) Showing granular cells with vacuolated cytoplasm $(\rightarrow)$. (B) Numerous immature neurons in the sub granular zone $(\rightarrow)$. (Alzheimer model group, $\mathrm{H} \& \mathrm{E}, \times 400)$

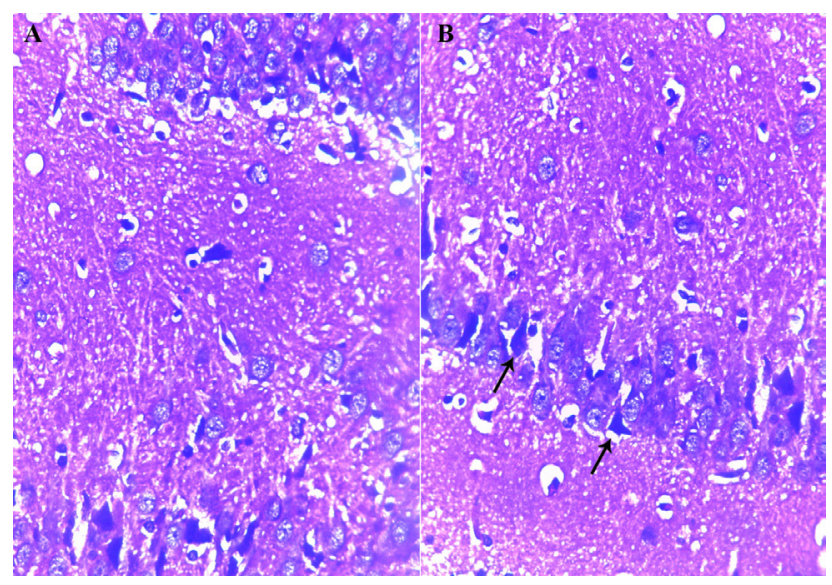

Fig. 8: (A) Showing disturbed arrangement and reduction of the polymorphic cell layer. (B) Shrunken pyramidal cells $(\rightarrow)$ with darkly stained pyknotic nuclei. (Alzheimer model group, H\&E, × 400)

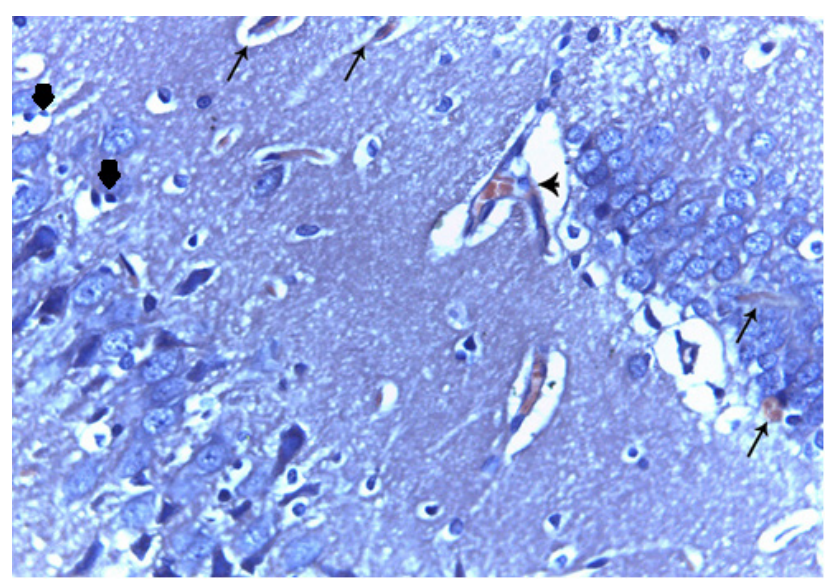

Fig. 9: Showing amyloid deposition with orange coloration $(\rightarrow)$ in the granular layer. Notice dilated congested blood capillaries $(\longrightarrow)$. Also, large vacuolated cells with darkly stained pyknotic nuclei(thick arrow). (Alzheimer model group, Congo red stain, $\times 400$ )

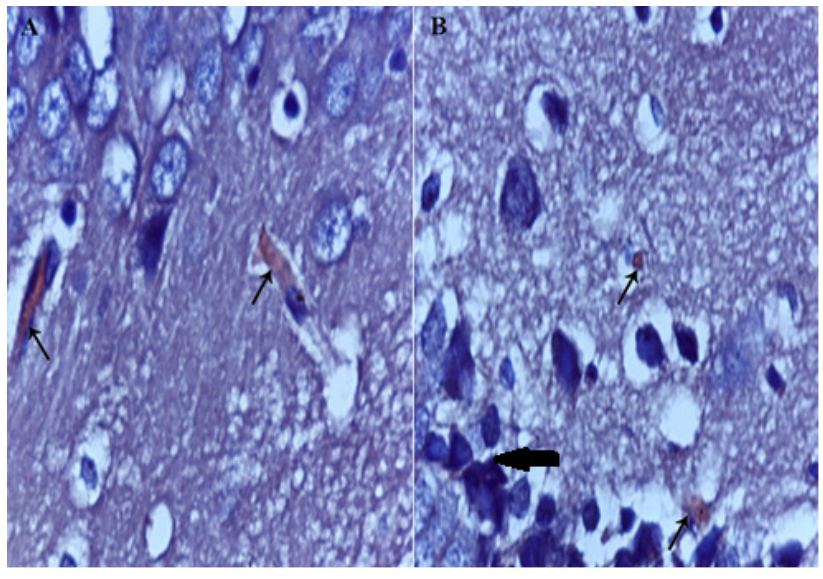

Fig. 10: (A) Amyloid deposition with orange coloration $(\rightarrow)$ in the granular layer. (B) Deposition of amyloid in the polymorphic layer $(\rightarrow)$. Notice the increased number of immature cells (thick arrow). (Alzheimer model group, Congo red stain, $\times 1000$ )

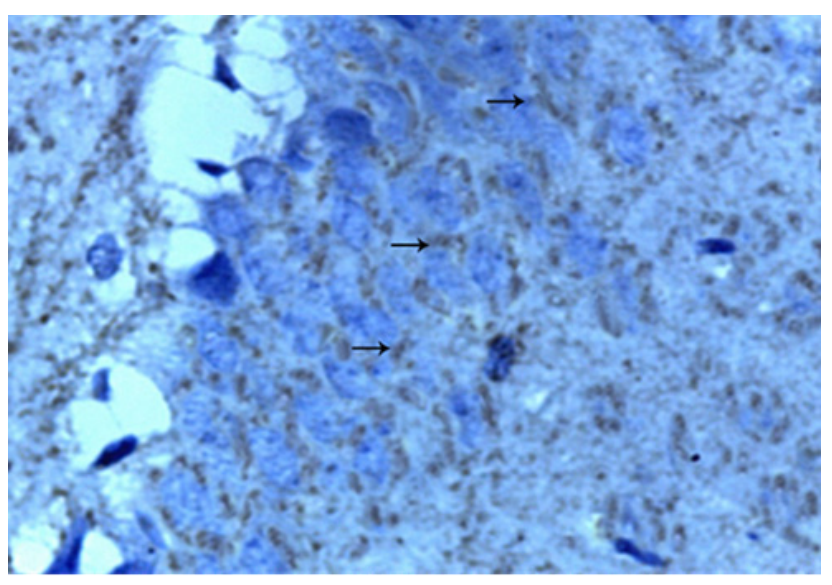

Fig. 11: Showed Increased expression INOS antibody in the granular cell layer of the dentate gyrus. (Alzheimer model group, imunoperoxidase staining, $\times 1000)$

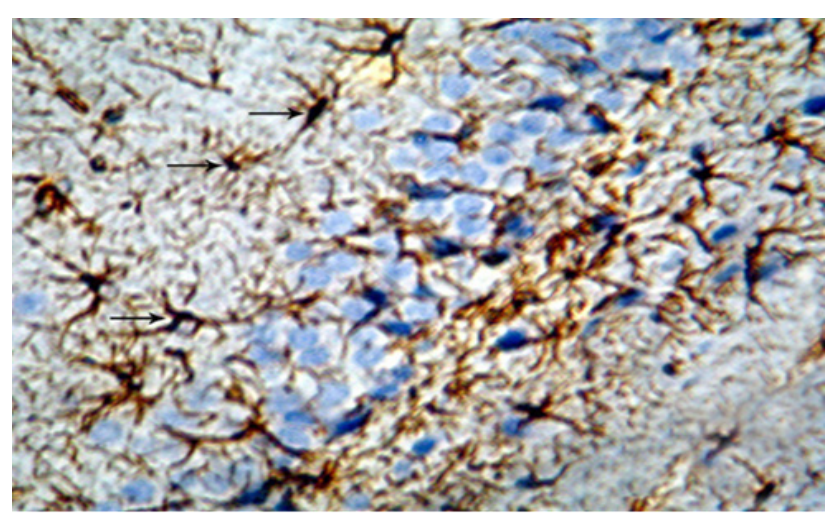

Fig. 12: Showing apparent increase in GFAP immunoreactivity. The astrocyte appear increased in number and larger in size, with longer processes .(Alzheimer model group, GFAPimmunostaining, $\times 400$ ) 


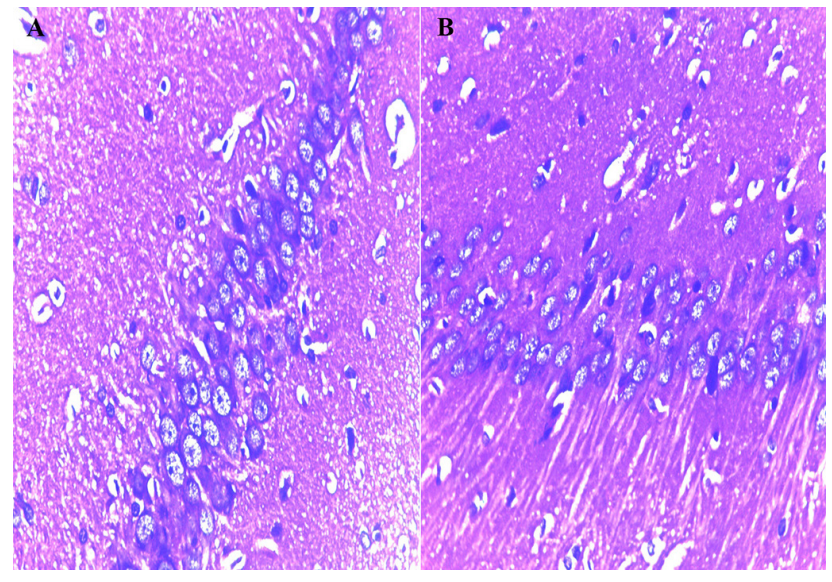

Fig. 13: (A) The granular cell layer and (B) the polymorphic layer of the dentate gyrus; both layers are similar to those of the control group. (Geniposide-treated group, H\&E, × 400)

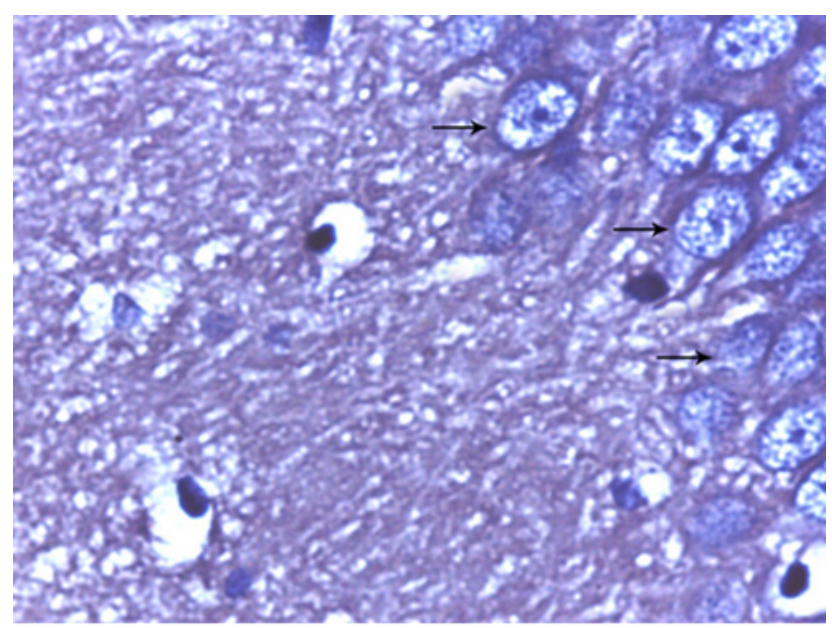

Fig. 14: The granular cell layer of the dentate gyrus; are similar to those of the control group.(Geniposide-treated group, Congo red stain, $\times 1000)$

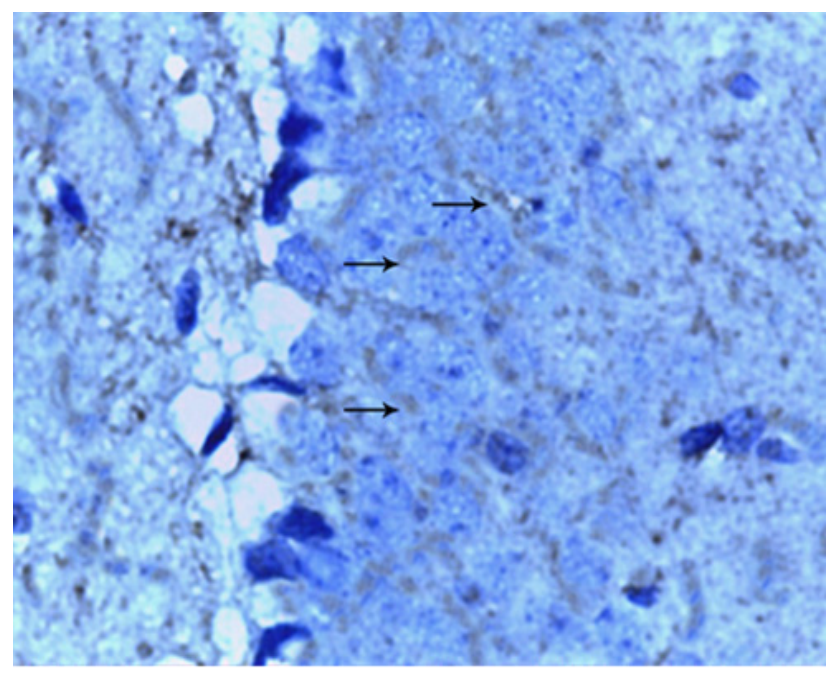

Fig. 15: Decreased cytoplasmic immunoreactivity in the granular cell layer of the dentate gyrus. (Geniposide-treated group, INOS immunostaining, $\times 1000)$

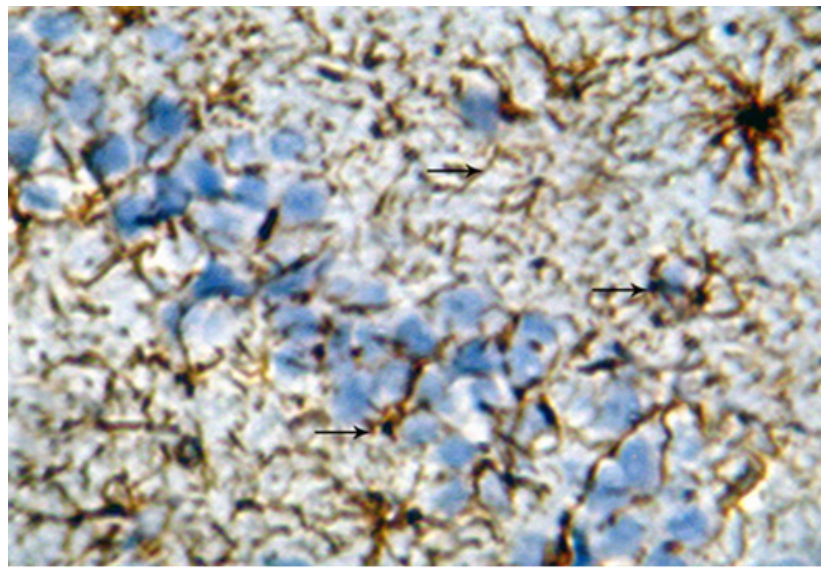

Fig. 16: Shpwing apparent decrease in GFAP immunoreactivity. The astrocyte are less in in number and processes.(Alzheimer model group, GFAPimmunostaining, $\times$ 400)
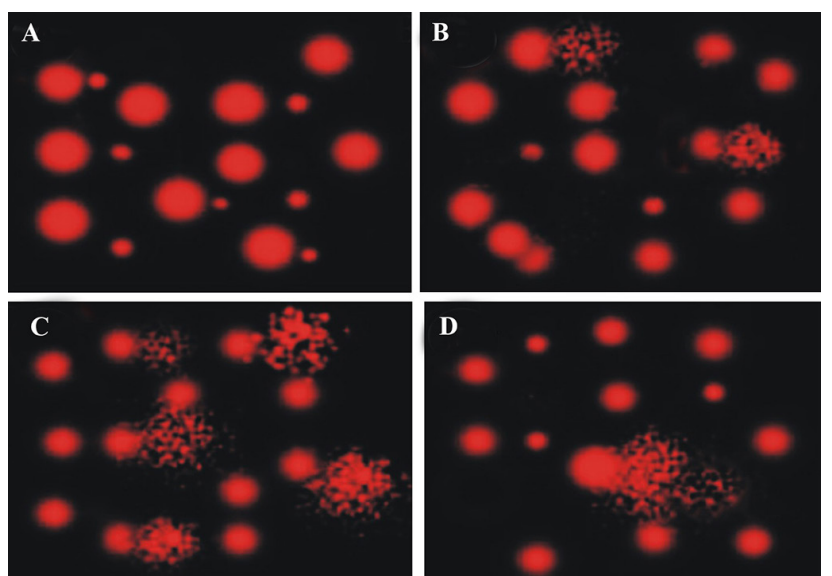

Fig. 17: Photomicrographs representation of DNA damage in brain tissues, using comet assay, in normal control group (A), Alzheimerinduced model group $(\mathrm{B}, \mathrm{C})$ and geniposide-treated group (D).

Table 1: Showing the mean + SD of area percentage of positive INOS immunoreaction, and positive GFAP immunoreaction, in different study groups.

\begin{tabular}{cccc}
\hline & Control & AD group & $\begin{array}{c}\text { Geniposide } \\
\text { group }\end{array}$ \\
\hline $\begin{array}{l}\text { Area \% of INOS } \\
\text { immunoreaction }\end{array}$ & $0.18+0.02$ & $0.26+0.03$ & $0.21+0.02$ \\
$\begin{array}{c}\text { Area \% of GFAP } \\
\text { immunoreaction }\end{array}$ & $1.44+0.06$ & $6.53+0.16$ & $2.22+0.3$ \\
\hline
\end{tabular}

Values are expressed as mean $+\mathrm{SD}$

Table 2: Comet assay parameters obtained by image analysis in cells of all groups after treatment experiment

\begin{tabular}{cccccc}
\hline Group & Tailed\% & Untailed\% & $\begin{array}{c}\text { Tails length } \\
\mu \mathrm{m}\end{array}$ & $\begin{array}{c}\text { Tail } \\
\text { DNA\% }\end{array}$ & $\begin{array}{c}\text { Tail } \\
\text { moment }\end{array}$ \\
\hline G1 & 1.5 & 98.5 & $1.35+0.09 \mathrm{~d}$ & 1.45 & 1.96 \\
$\mathrm{G} 2$ & 22 & 78 & $7.04+0.29 \mathrm{a}$ & 5.90 & 41.54 \\
$\mathrm{G} 3$ & 12 & 88 & $4.58+0.15 \mathrm{~b}$ & 3.67 & 16.81 \\
\hline
\end{tabular}

Different superscript letters in the same column of tail length shoed significance difference at $(P<0.05)$ 


\section{DISCUSSION}

Aluminum is considered the third most abundant element in nature and its wide spread industrial utilization has stimulated considerable attention in the possible environmental toxicity of this metal[ ${ }^{[23]}$. Aluminum compound have been used for many years in food items, in water provided by regional water supplies and in medication as eye drops, vaccines and in control phosphate levels in patients undergoing hemodialysis ${ }^{[9]}$.

Aluminum is considered a potential etiological factor in cognitive dysfunction and neurodegenerative facts. The neurotoxic effect arising from the aluminum was due to interfering with a diversity of cellular metabolic processes in the nervous system and other systems. Many researchers have found that elevated Al levels contributes to a decline in visual memory, concentration, lower vocabulary scores in hemodialysis patients and variety of cognitive impairment in workers exposed to al dust in industrial environments ${ }^{[24]}$. The neurotoxicity from excess human brain exposure to $\mathrm{Al}$ has been documented by animal experiments and clinical observations ${ }^{[25]}$. Experimentally, it was proved that exposure to aluminum causes brain oxidative damage, neuronal inflammation, neurofilamentous and neurodegeneration changes in the cerebral cortex and in the hippocampus where in it accumulates significantly and also exacerbates biochemical changes in cases of $\mathrm{AD}^{[9]}$.

In the present study, the Alzheimer-induced model group showed significantly impaired learning and spatial memory in rats during the passive avoidance test compared to control group which was in agreement with previous studies $^{[26]}$. Histological examination of the dentate gyrus of the Alzheimer-induced model group showed shrunken dentate gyrus, distortion of the granular cell layer with vacuolated cytoplasm, many immature neurons, distortion and reduction of pyramidal cells with darkly stained pyknotic nuclei. Detection of extracellular amyloid plaques and significant increased intensity of INOS within the granular cell layer was also observed. These results coincide with previous studies which reported that overload of aluminum chloride in rats caused neurotoxicity via free radical production, peroxidation damage to lipid, proteins. The great affinity of aluminum chloride to bio- membrane with the ability to enhance formation and aggregation of insoluble $\mathrm{AB}$ plaques and deposition of intracellular highly phosphorylated tau protein neurofibrillary tangle with loss of neuron and synapses in the cerebral cortex and the hippocampal brain tissue leading to progressive dementia and cognitive impairment in Alzheimer brain ${ }^{[8}$ and 25$]$.The reduction in number and distortion of pyramidal cells and all the brain structural changes attributed to oxidative damage of Aluminum and contributes to the pathogenesis of $\mathrm{AD}^{[27]}$. It has been described that the mechanism of cytotoxicity and neurotoxicity of most agents are due to the oxidative stress included in the formation of reactive oxygen species (ROS), that include hydrogen peroxide, superoxide anion, hydroxyl radical and superoxide radical ${ }^{[28,29]}$. The oxidative damage degree is based on the balance between the efficiency of the antioxidant mechanism and the oxidative stress that found in many cells ${ }^{[30]}$. As the brain tissue are highly sensible to be attacked by free radicals due to its highly unsaturated lipid compound especially in the axonal layer in hippocampus than the cortical region, low mitotic rate, high oxygen turnover and its low level of antioxidant enzymes $^{[31]}$.

In the current study there are many immature neurons in the dentate gyrus with apparent reduction in of the mature granular cells. These results were supported by other researches ${ }^{[32]}$ who reported that oxidative damage associated neuronal cell death and the newly formed neurons in the dentate gyrus in $\mathrm{AD}$ do not become mature neurons as Al causes damage to the brain by free-radical oxidative stress causing damaging neural membranes.

Amyloidogenesis hypothesis has turn into prevailing central pathogenic incident in $\mathrm{AD}^{[33]}$. Revelation of amyloid plaques in the Alzheimer-induced model group was consistent with that of other reports who described that the amyloid- $\beta$ aggregates found around neurons have a direct toxic effect on the neurons and promote the neuronal cell susceptibility to free radicals and the other toxic factors. Also the accumulating evidences proved that oxidative stress and cholinergic dysfunction could be included in the pathogenesis of amyloid- $\beta$ toxicity leading to wide spread neuroinflammation and neurodegenration. The previous authors added that when Amyloid- $\beta$ present in high concentration, it forms fibrillar insoluble $A \beta$ plaques that enhance ion channels in the cell membrane inducing membrane depolarization and destabilization of intracellular calcium homeostasis. Moreover, $A \beta$ oligomers induce intracellular $\mathrm{Ca}+$ overload causing neuronal death $^{[34-35]}$. Recent evidence reveal that aggregation of $\mathrm{A} \beta$ as soluble extracellular high molecular weight oligomeric $\mathrm{A} \beta$ species, rather than amyloid plaques deposition, may be specifically belong to spatial memory deficits in $\mathrm{AD}$. $\mathrm{A} \beta$ assembly is an intricate event that is considered complex than a simple conversion of soluble monomer into digomer to fibrils ${ }^{[36]}$. There are many types of different aggregate morphologies, including the soluble oligomers, protofibrils, diffuse plaques, and fibrillar deposits that could be seen in these senile plaques. These aggregated patterns appear to be dominated by called $\beta$-sheet structure and the crucial form determining amyloid- $\beta$ toxicity is the aggregation state. Therefore, a key evidence in $\mathrm{AD}$ pathogenesis is the conversion of $\mathrm{A} \beta$ peptide from soluble monomer to aggregated forms in the brain ${ }^{[37]}$. Other reports mentioned that $\beta$-amyloid is a protein fragment over expression of human amyloid precursor protein. These fragments can be eliminated in healthy neuronal tissue and in $\mathrm{AD}$ the protein fragments accumulate to form hard insoluble plaques leading to disrupting the cell's calcium ion homeostasis and apoptosis in hippocampus neurons ${ }^{[38]}$.

In the current study amyloid plaques were detected in congo red stained section of the dentate gyrus in the Alzheimer-induced models. These findings were reported by other authors who demonstrated that congo red staining 
detects the amyloid aggregates in the brain neuronal tissue of amyloid precursor protein transgenic experimental mice and in brain tissue of patients with $\mathrm{AD}^{[39]}$. The congo red stain, have a role to detect amyloidosis, turns the semicrystallized $\beta$-sheet protein a bright salmon orange which attributed to the great affinity of congo red for amyloid aggregates which has been proved for a long period $^{[40]}$.

The neurotoxic effects of A1 have been repeatedly demonstrated and shown to play a role in the development and the relationship between A1 and neurofibrillary tangles (NFTs) which were explained as brain intracellular twisted insoluble fibers ${ }^{[1]}$. The neurofibrillary tangles contain the abnormally hyperphosphorylated forms of tau protein which is a highly soluble microtubule-associated protein found in the axonal part of the neuron and is involved in microtubule stabilization, homeostasis, axonal transport and synaptic function ${ }^{[42]}$. The microtubules integrity is maintained by the phosphorylation state of tau protein that is regulated by many kinases and phosphatases. Glycogen synthase kinase-3 (GSK3) has been known as the kinase responsible for the hyperphosphorelation of tau protein $(\tau)$ in $\mathrm{AD}^{[43]}$. As $\tau$ protein phosphorylated leading to disassembling of microtubules and can aggregate when hyperphosphorylated to form NFTs and then, $\tau$ protein loses its connecting function to tubulin with no longer role in microtubule assembly ${ }^{[2]}$. In $\mathrm{AD}$ tau protein undergoes chemical changes and pair with other threads, creating neurofibrillary tangles ${ }^{[44]}$. Studies shows that Al might implicate in the hyperphosphorelation of tau in $\mathrm{AD}^{[45]}$. As the tau protein can be phosphorylated by glycogen synthase kinase-3(GSK3), a large body of genetic, biochemical and cell biological evidences involved GSK3 as a main enzymes responsible for regulation of tau phosphorylation and is considered as a key regulator in glycogen synthesis ${ }^{[46]}$.

The enzymatic activity of GSK3 is regulated as follow: phosphorylation at tyrosine-216 in GSK3 $\beta$ (GSK P-Y216) increases the enzymatic activity, while phosphorylate of serine- 9 in GSK $3 \beta$ decreases the activity and the dysregulation of GSK3 is associated with multiple pathological changes in $\mathrm{AD}^{[47]}$. In this study we used western blot assay to show that A1 induced activation of GSK $3 \beta$, increase the active form of (GSK3 $\beta$ (P-Y216) but, decrease the inactive form of GSK $3 \beta$ (PS9). The geniposide treatment decreases the excessive GSK3 $\beta$ activity and could promote the ameliorating of the tau hyperphosphorylation. However, previous studies explained that the antioxidant effect of geniposide may include many signal transduction pathways through a cascade of interactions between protein kinase- $\beta$ phosphoinositol-3 kinase, and glycogen synthase kinase- $3 \beta$ (GSK-3 $\beta$ ) under conditions of oxidative stress ${ }^{[46]}$. Those authors added that medications that are used in treatment of diabetes could be effective in $\mathrm{AD}$ animal models as glucagons-like peptide (GLP-1), which improve insulin signaling could ameliorate AD pictures in animal models. Geniposide is an iridoid glycoside present in the fruit of Gardenia Jasminoides which may act as a GLP-1 receptor agonist that can be used in the treatment of $\mathrm{AD}$ in animal models ${ }^{[46]}$.

This study revealed increased INOS expression in the granular cell layer of the dentate gyrus of hippocampus of the Alzheimer-induced model and administration of geniposide significantly reduced the INOS immune expression in the rat model. In agreement with these findings many studies reported that increased neuronal INOS expression have demonstrated in the $\mathrm{AD}$ brain tissue ${ }^{[48]}$. Also, the excessive production of nitric oxide was reported in $\beta$-amyloid peptide-induced brain dysfunction. They added that significant increase in INOS expression was involved in brain tissue in case of inflammatory process with neurodegenerative disorders, in aged brain and in the CNS under pathological conditions ${ }^{[49]}$. The formation of reactive oxygen species are the potential neurotoxic effect of A1 that enhance its possible role in AD. Therefore, it is suggested that INOS-generated NO could be a free radicals that has involved in neurodegenerative disorders. It was confirmed that INOS derived NO is an important mediator of neurotoxicity in $\mathrm{AD}$ and the source of the cytotoxic level of NO is from glial cells that have been stimulated with AD. However, NO could diffuse into surrounding neurons and can execute apoptotic death in them by activation of the apoptotic cascade. Moreover, up-regulatation proapoptotic factors or down-regulation of anti-apoptotic factors and can induce mitochondrial dysfunction which have been reported to be a primary target effect of oxidative free radicals $\mathrm{NO}^{[50]}$.

In the present study, comet assay was used to detect any prospective damage for DNA strands in Alzheimerinduced model by measuring the migration of DNA from immobilized nuclear DNA. The present results showed that DNA damage was significantly increased in AD brain tissue that was indicated by DNA comet .This increase of DNA damage was reduced after administration of geniposide. These results were in accordance with previous authors who reported that oxidative modification of nucleic acids results in DNA breakage that led to increased apoptosis. In addition, NO can react with superoxide producing peroxynitrite agent. The peroxynitrite act as strong oxidizing element that react with different biomoleates, cause generation of oxidative stress inducing damage of DNA and participate directly in the mechanisms triggering neurodegeneration and $\mathrm{AD}^{[51]}$. In the same line, previous reports explained that release of ROS attack DNA and result in DNA strand breaks and fragmentation increasing cytochrome release from mitochondria to cytosol and apoptosis $^{[52]}$.

Astrocytes' number and size demonstrated by GFAP area $\%$, were significantly increased in $\mathrm{AD}$-induced model in the present study. Previous researchers stated that astrocytes became more clustered and fibrous with increased concentration of GFAP proteins and mRNA prevalence were demonstrated in $\mathrm{AD}$ and in neurodegenerative disease as a compensatory reaction to 
neuronal degeneration ${ }^{[53]}$. The mean size and number of GFAP-immunoreactive astrocytes in the hippocampus of Alzheimer diseased rats were reported to be significantly increased ${ }^{[54]}$. This is supported by previous studies stated that in neurodegenerative disease, astrocyte and other glial cells with cytokines are activated in response to misfolded proteins in the tissue of the brain, regulating tissue homeostasis and preserving the structural and functional characteristics of the brain ${ }^{[55]}$. Moreover, the activation of astroglial cells was in close association to the damaged neurons. The accumulation of astrocytes and glial cells around amyloid plaques with strong upregulation of inflammatory markers has proved that glial cell proliferation is the main element of the disease process. Therefore, increased astrocytes immunoreactivity in polymorphic layer and in the molecular layer in the present study could explain the role of astrocytes in synaptogenesis and might be attributed to the abundance of synapses in these layers which were reported as the most important link in memory consolidation ${ }^{[56]}$. Geniposide performs its antiinflammatory activity by suppression of NO generation, cyclooxygenase expression and interfering with the release of the proinflammatory cytokines ${ }^{[57]}$.

Examination of geniposide treated rats, revealed significant improvement in all tested cognitive functions and a similar dose of geniposide has been shown to improve cognitive function and to slow functional decline in Alzheimer disease transgenic rat models ${ }^{[13]}$. Histological examination of geniposide treated group ,the dentate gyrus of hippocampus revealed a more or less normal structure and most of the structural changes occurred in Alzheimer-induced model was ameliorated. These results are in accordance with other authors who reported that geniposide is considered as the most important antioxidant. The geniposide is involved in the activation of antioxidant signaling pathways and may be a promising therapeutic agent for ameliorating cognitive disorders and attenuating apoptosis in $\mathrm{AD}^{[58]}$

Consequently, compounds which inhibit AB fibrillation, aggregation or plaque formation can protect neurons from $\mathrm{AB}$ toxicity and provide therapeutic potential for the $\mathrm{AD}^{[59]}$. Geniposide may bind to a region in $\mathrm{AB}$ and stabilize the proteins intra molecular interactions. As the plaques composed of amyloid B large mass polymers are less toxic than the soluble oligomer. In addition, researches revealed that amyloid $\mathrm{B}$ oligomers in $\mathrm{AD}$ related to the neuronal loss, astrocyte inflammatory response and the cognition impairment ${ }^{[60]}$. Geniposide can modulate the folding pathway of aggregation prone polypeptides and therefore prevents their assembly into toxic aggregation elements. Moreover geniposide with the potential to generate less cytotoxic fibrillogenesis of $\mathrm{AB}$ may be an opportunity for early therapy of $\mathrm{AD}^{[61]}$.

Previous study demonstrated that geniposide as an antioxidants can inhibit and even reverse the deposition of amyloid aggregates in brain tissue of AD. Moreover, geniposide's antioxidants neutralize the peroxynitrite, significantly reduces oxidative stress and increase the mitochondrial membrane potential in addition to reducing lipid oxidation through enhance the activites of crucial internally generate antioxidants as superoxide dismutase, melatonin and glutathione peroxidase ${ }^{[62]}$.

Some researches hypothesize that decrease of abnormal phosphorylation an important target for development of therapeutic interventions for tauopathies in $\mathrm{AD}$. They reported that geniposide could greatly decrease $\tau$ aggregation, reverse, $\tau$ hyperphosphorelation, blocking the abnormal $\tau$ phosphorelation and preventing the spread of $\tau$ pathology in the brain tissue of $\mathrm{AD}^{[63,12]}$. Moreover it has been reported that geniposide has anti-inflammatory properties and can enhance activation of glial cells through inflammatory cytokines and by suppression of both NO production and cyclooxygenase expression.

Geniposide, an iridoid glucoside, is a major component $(>2 \%)$ in the fruits of Gardenia Jasminoides Ellis and is a novel drug candidate for $\mathrm{AD}$ treatment with its multiple roles in neuroprotection. Because the continues increase of world's aging population and the AD treatment is still a common problem, the geniposide therapeutic potential that may prevent the onset of neuronal disorders, became greatly desirable. Geniposide therapeutic targets and molecular mechanisms need further research. Geniposide is orally active, easy to administer, water soluble, can cross the BBB and safe to take. The findings in this study describe the possible mechanisms of neuroprotective effects of geniposide :decrease $\mathrm{AB}$ toxicity, mitochondrial dysfunction, Oxidative stress, tau phosphorelation and inflammation. The chinese traditional medicine geniposide could serve as a novel therapeutic agent of sporadic AD in the early stage of process of the disease to prevent or delay the incedence and progression of the irreversible cognitive disorders. Clinical trials in $\mathrm{AD}$ patients are warranted to explain this hypothesis.

\section{CONFLICTS OF INTEREST}

The authors have no conflicts of interest to declare.

\section{REFERENCES}

1. Götz J, Ittner A and Ittner LM (2012): $\tau$-targeted treatment strategies in Alzheimer's disease. Br. J. Pharmacol. 165: 1246-1259.

2. Ma T, Tan M, Yu J and Tan L (2014): Resveratrol as a therapeutic agent for Alzheimer's disease. Biomed. Res. Int., 350516.

3. Antero S, Anu K, Tiina S, Kai K and Johanna O (2009): ER stress in Alzheimer's disease: a novel neuronal trigger for inflammationand Alzheimer's pathology. J. Neuroinflamm. 6: 41.

4. Alzheimer's - Association, (2014):"2014 Alzheimer's disease facts and figures," Alzheimer's and Dementia, vol. 10, no. 2, pp. e47-e92.

5. Fantini J and Yahi N (2010): Molecular insights into amyloid regulation by membrane cholesterol 
and sphingolipids: common mechanisms in neurodegenerative diseases. Expert Rev Mol Med. 12: 27.

6. Mungrue IN, Stewart DJ and Husain M (2003): The Janus faces of iNOS. Circ. Res. 93(7):e74.

7. Mungrue IN, Bredt DS, Stewart DJ and Husain M (2003): From molecules to mammals: What's NOS got to do with it? Acta Physiol.Sc and. 179(2): 123-135.

8. Buraimoh AA, Ojo SA, Hambolu JO and Adebisi SS (2011): Effects of oral administration of aluminium chloride on the histology of the hippocampus of wistar rats. Curr Res J Biol Sci. 3:509-515.

9. Kawahara M and Kato-Negishi M (2011): Link between aluminum and the pathogenesis of Alzheimer's disease: the integration of the aluminum and amyloid cascade hypotheses. Int $\mathrm{J}$ Alzheimers Dis. 8:276-393.

10. Chen QC, Zhang WY, Kim H, Lee IS, Ding Y, Youn UJ, Lee SM, Na M, Min BS, and Bae K (2010): Effects of Gardeniae fructus extract and geniposide on promoting ligament cell proliferation and collagen synthesis. Phytother. Res. 24: S1-S5.

11. Wang J, Li PT, Du H, Hou JC, Li WH, Pan YS and Chen HC (2012b): Tong Luo Jiu Nao injection, a traditional Chinese medicinal preparation, inhibits MIP-1 expression in brain microvascular endothelial cells injured by oxygen-glucose deprivation. J. Ethnopharmacol. 141: 151-157.

12. Gao C, Liu Y, Jiang Y, Ding J, and Li L (2014): Geniposide ameliorates learning memory deficits, reduces $\tau$ phosphorylation and decreases apoptosis via GSK3 $\beta$ pathway in streptozotocin-induced Alzheimer rat model. Brain Pathol. 24: 261-269.

13. Lv C, Wang L, Liu X, Yan S, Yan SS, Wang Y and Zhang W (2015): Multi-faced neuroprotective effects of geniposide depending on the RAGEmediated signaling in an Alzheimer mouse model. Neuropharmacology 89: 175-184.

14. Saab BJ, Georgiou J, Nath A, Lee FJS, Wang M, Michalon A, et al. (2009): NCS-1 in the dentate gyrus promotes exploration, synaptic plasticity, and rapid acquisition of spatial memory. Neuron. 63:643-656.

15. Amaral DG, Scharfman HE and Lavenex P (2007): The dentate gyrus: fundamental neuroanatomical organization (dentate gyrus for dummies). Prog Brain Res. 163:3-22.

16. Buraimoh AA, Ojo SA, Hambolu JO, Adebisi
SS (2011): Effects of Oral Administration of Aluminium Chloride on the Histology of the Hippocampus of Wistar Rats. Current Research Journal of Biological Sciences . 3(5):509-515.

17. Yao DD, Yang L, Wang Y, Liu C, Wei YJ, Jia XB, Yin W, Shu L(2015): Geniposide promotes betacell regeneration and survival through regulating $\beta$-catenin/TCF7L2 pathway. Cell Death and Disease ,6, e174

18. Almonte AG, Hamill CE, Chhatwal JP (2007): Learning and memory deficits inmice lacking protease activated receptor-1. Neurobiol Learn Mem.; 88(3): 295-304.

19. Kumar G and Kiernan JA (2010): Education guide, special stains and H\&E. 2nd ed., Chapter 8. North America, Carpinteria, California: staining sections of the central nervous system. 67.

20. Survarna SK, Layton C,Bancroft JD (2013): Bancroft's Theory and practice of histological techniques. 7th ed, Churchill Livingstone. UK, El Sevier ; pp: 408-504.

21. C'evik Ö, Ers'ahin M, S'ener TE, Tinay I, Tarcan T, C'etinel S , et al. (2013): Beneficial effects of quercetin on rat urinary bladder after spinal cord injury. J Surg Res;183:695e703.

22. Singh NP, McCoy MT, Tice RR, and Schneider EL. (2000): A simple technique for quantification of low levels of DNA damage in individual cells. Exp. Cell Res. 175:184-191.

23. Van Hoesen GW, Augustinack JC, Dierking J, Redman SJ and Thangavel R. (2000): The parahippocampal gyrus in Alzheimer's disease. Clinical and preclinical neuroanatomical correlates. Ann. N. Y. Acad. Sci. Jun, 911: 254-274.

24. Walton JR.(2006): Aluminum in hippocampal neurons from humans with Alzheimer's disease. Neurotoxicology, 27(3):385-394.

25. Walton JR (2007): An aluminum-based rat model for Alzheimer's disease exhibits oxidative damage, inhibition of PP2A activity, hyperphosphorylated tau and granulovacuolar degeneration. J. Inorg. Biochem, 101(9):1275-1284.

26. Popovic M, Biessels GJ, Isaacson RL, et al. (2001): Learning and memory in streptozotocin induced diabetic rats in a novel spatial/ object discrimination task. Behav Brain Res.; 122(2): 201-207.

27. Rodella LF, Ricci F, Borsani E, Stacchiotti A, Foglio E, Favero G, et al. (2008): Aluminium exposure induces Alzheimer's disease-like histopathological alterations in mouse brain. Histol Histopathol. 23:433-439. 
28. Axelsen P, Komatsu H and Murray I (2011): "oxidative stress and cell membranes in the pathogenesis of Alzheimer's disease," Physiology. 26(1): 54-69.

29. Gella and Bolea I (2011): "Oxidative stress in Alzheimer's disease: pathogenesis, biomarkers and therapy," in Alzheimer's disease pathogenesiscore concepts, shifting paradigms and therapeutic targets, Rijeka, Croatia: InTech. 319-344.

30. Di J, Yao K, Han W and Bi S (2006): Study on the interaction of copper-zinc superoxide dismutase with aluminum ions by electrochemical and fluorescent method. Spectrochim Acta A Mol Biomol Spectrosc. 65:896-900.

31. Kumar V and Gill KD (2014): "Oxidative stress and mitochondrial dysfunction in aluminium neurotoxicity and its amelioration: a review," NeuroToxicology. 41: 154-166.

32. Li B, Yamamori H, Tatebayashi Y, Shafit-Zagardo B, Tanimukai H, Chen S, et al. (2008): Failure of neuronal maturation in Alzheimer disease dentate gyrus. J Neuropathol Exp Neurol. 67:78-84.

33. Tam JH and Pasternak SH (2012): Amyloid and Alzheimer's disease: inside and out. Can J Neurol Sci. 39:286-298

34. Lee S, Fernandez EJ and Good TA (2007): Role of aggregation conditions in structure, stability, and toxicity of intermediates in the A beta fibril formation pathway. Protein Sci 16:723-732.

35. Alberdi E, Sánchez-Gómez MV, Cavaliere F, Pérez-Samartín A, Zugaza JL, Trullas R, et al. (2010): Amyloid beta oligomers induce $\mathrm{Ca} 2+$ dysregulation and neuronal death through activation of ionotropic glutamate receptors. Cell Calcium. 47:264-72.

36. Ehrnhoefer DE, Bieschke J, Boeddrich A et al. (2008): "EGCG redirects amyloidogenic polypeptides into unstructured, offpathway oligomers," Nature Structural and Molecular Biology. 5(6): 558-566.

37. Dickson DW, Farlo J, Davies P, Crystal H, Fuld P and Yen SHC (1988): “Alzheimer's disease. A double-labeling immunohistochemical study of senile plaques," American Journal of Pathology. 132,(1): 86-101.

38. O'Brien RJ and Wong PC (2011): Amyloid precursor protein processing and Alzheimer's disease. Annu Rev Neurosci. 34:185-204.

39. Wilcock DM, Gordon MN and Morgan D (2006): Quantification of cerebral amyloid angiopathy and parenchymal amyloid plaques with Congo red histochemical stain. Nat Protoc. 1:1591-1595.

40. Elhaddaoui A, Pigorsch E, Delacourte A and Turrell S (2004): Competition of Congo red and thioflavin $\mathrm{S}$ binding to amyloid sites in Alzheimer's diseased tissue. Biospectroscopy. 1:351-356.

41. Iqbal K, Liu F, Gong CX and Iqbal IG (2010): Tau in Alzheimer disease and related tauopathies. Curr Alzheimer Res. 7:656-664

42. Hashiguchi $M$ and Hashiguchi $T$ (2013): Kinase-kinase interaction and modulation of $\tau$ phosphorylation. Int. Rev. Cell. Mol. Biol. 300: 121-160.

43. Llorens-Martin M, Jurado J, Hernandez F and Avila $\mathrm{J}$ (2014): GSK-3 $\beta$, a pivotal kinase in Alzheimer disease. Front. Mol. Neurosci. 7: 46.

44. Hernández F and Avila J (2007): Amyloid $\beta$-Protein of Alzheimer's disease: more than just a plaque 'Tauopathies'. Cell Mol Life Sci. 64:2219-2233.

45. Zhang C, Li Y, Wang C, Lv R and Song T (2013): Extremely low-frequency magnetic exposure appears to have no effect on pathogenesis of Alzheimer's disease in aluminum-overloaded rat. PLoS One. 8(8):e71087.

46. Li L, Zhang ZF, Holscher C, Gao C, Jiang YH and Liu YZ (2012): (Val(8)) glucagons-like peptide-1 prevents tau hyperphosphorylation, impairment of spatial learning and ultra-structural cellular damage induced by streptozotocin in rat brains. Eur J Pharmacol 674:280-286.

47. Gao C, Holscher C, Liu Y and Li L (2012): GSK3: a key target for the development of novel treatments for type 2 diabetes mellitus and Alzheimer disease. Rev Neurosci. 23:1-11.

48. Seham AE, Saadia R and Rehab A (2008): Upregulation of the inducible nitric oxide synthase in rat hippocampus in a model of Alzheimer's disease: a possible mechanism of aluminium induced Alzheimer's. Egypt J Histol. 32:173-180.

49. Law A, O'Donnell J, Gauthier S and Quirion R. (2002): Neuronal and inducible nitric oxide synthase expressions and activities in the hippocampi and cortices of young adult, aged cognitively unimpaired and impaired Long-Evans rats. Neuroscience, 112(2):267-275.

50. Polster BM and Fiskum G (2004): Mitochondrial mechanisms of neural cell apoptosis. J. Neurochem, 90(6):1281-1289.

51. Acquaviva R, Campisi A, Murabito P, Raciti G, Avola R, Mangiameli S, Musumeci I, Barcellona ML, Vanella A and Li Volti G (2004): Propofol attenuates peroxynitrite-mediated DNA damage 
and apoptosis in cultured astrocytes: An alternative protective mechanism. Anesthesiol, 101(6):1363-1371.

52. Farombi EO and Onyema OO (2006): Monosodium glutamate-induced oxidative damage and genotoxicity in the rat : modulatory role of vitamin $\mathrm{C}$, Vitamine $\mathrm{E}$ and quercetin.Hum Exp Toxicol.,25(5):251-259.

53. Vanzani MC, Iacono RF, Caccuri RL and Berria MI (2005): Immunochemical and morphometric features of astrocyte reactivity vs. plaque location in Alzheimer's disease. Medicina (B. Aires). 65(3): 213-218.

54. Fakhoury M (2015): Role of immunity and inflammation in the pathophysiology of neurodegenerative diseases. Neurodegener. Dis. Epub ahead of print.

55. Heneka MT, Kummer MP and Latz E (2014): Innate immune activation in neurodegenerative disease. Nat. Rev. Immunol. 14: 463-477.

56. Rubio-Perez JM and Morillas-Ruiz JM (2012): A review: inflammatory process in Alzheimer's disease, role of cytokines. Sci. World J., 756357.

57. Song X, Zhang W, Wang T, Jiang H, Zhang Z, Fu Y, Yang Z, Cao Y and Zhang N (2014): Geniposide plays an anti-inflammatory role via regulating TLR4 and downstream signaling pathways in lipopolysaccharide-induced mastitis in mice. Inflammation. 37: 1588-1598.
58. Song J, Hur BE, Bokara KK, Yang W, Cho HJ, Park KA, Lee WT, Lee KM and Lee JE (2014): Agmatine improves cognitive dysfunction and prevents cell death in a streptozotocin-induced Alzheimer rat model. Yonsei Med J. 55(3):689-99.

59. Darocha-Souto B, Scotton TC, Coma M et al. (2011): "Brain oligomeric $\beta$-amyloid but not total amyloid plaque burden correlates with neuronal loss and astrocyte inflammatory response in amyloid precursor protein/tau transgenic mice", Journal of Neuropathology and Experimental Neurology, 70(5): 360-376.

60. Hua Q, Ding HM and Liang M (2012): “Progress on A $\beta$-Targeted therapeutic strategies for Alzheimer's disease," Progress in Biochemistry and Biophysics. 39(8): 734-740. patients are warranted to explain this hypothesis.

61. Liu J, Yin F, Xiao H, Guo L and Gao X (2012): Glucagon-like peptide 1 receptor plays an essential role in geniposide attenuating lipotoxicity-induced $\beta$-cell apoptosis. Toxicol. In Vitro 26: 1093-1097.

62. Lv C, Liu X, Liu H, Chen T and Zhang W (2014): Geniposide attenuates mitochondrial dysfunction and memory deficits in APP/PS1 transgenic mice. Curr. Alzheimer Res. 11: 580-587.

63. Medina M and Avila J (2014): New perspectives on the role of $\tau$ in Alzheimer's disease. Implications for therapy. Biochem. Pharmacol. 88: 540-547. 


\section{الملخص العربى}

\section{التأثير الوقائي المحتمل لمستخلص الجاردينيا جاسمينويد على التلفيف

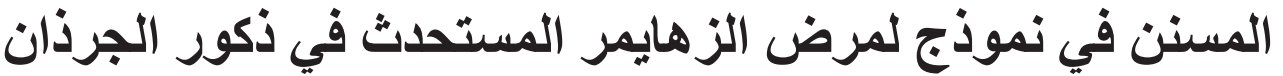 البيضاء البالغة : دراسة هستولوجية و هستوكيميائية مناعية}

\section{مها محمد ابو جازية \\ قسم علم الانسجة الطبية و بيولوجيا الخلية ـ كلية الطب- جامعة كفر الثيخ}

المقدمة : مرض الزهايمر من أهم الأمر اض العصبية و أكثرها شيوعاً و يعتبر من أهم اسباب التدهور التدريجي للقدر ات المعرفية و فقدان الذاكرة عند كبار السن ـ الجينيبوسايد هو مستخلص من عشب الجاردينيا جيسمينويد وهو استخدم على نطاق واسع لعلاج أمر اض الدماغ و تقليل نرسب بروتين (الامايولويد ) وهو عملية معقدة ومصاحبة لمرض الز هايمر. الهرف من البحث : إظهار التغير ات الهستولوجية في التلفيف المسنن في نموذج لمرض الزهايمر المستحدث و التاثير الوقائي المحتمل لمستخلص الجاردينيا جاسمينويد. مواد و طرق البحث : استخدم في هذا البحث ستة و ثلاثون من ذكور الجرذان البيضاء البالغة قسمت الي ثلاث مجمو عات متساوية ـ المجموعة الأولى و هي المجموعة الضابطة و المجموعة الثانية و هي نموذج مرض الزهايمر المستحدث و قد اعطيت كلوريد الالمونيوم المذاب في الماء المقطر بجر عة 300 ملليجر ام/كجم /اليوم عن طريق الفم لمدة شهر ـ المجموعة الثالثة و قد اعطيت كلوريد الالومونيو بنفس الجر عة السابقة و أيضا نفس المدة و لكن مع إعطاء الجينوبوسايد المذاب في الماء المقطر بجرعة 100 ملليجر ام /كجم / اليوم في نفس الوقت ـ في نهاية مدة التجربة تمت التضحيه بالجرذان و نم أخذ الصفوف الصدغية للأدمغة للار اسات النسيجية و الهستوكيميائية المناعية النتائج : أظهرت نتائج الفحص المجهري مجموعة نموذج مرض الزهايمر المستحدث تغيرات نسيجية واضحة في التلفيف المسنن حيث أظهرت طبقة الخلاية الحبييية نغيرات تنكسية في بعض خلاياها مع وجود زيادة في الخلايا العصبية الغير ناضجة كذلك ظهرت الخلايا الهرمية غير مرتبة في طبقة الخلايا المتعددة الاشكال مع وجود انكماش في بعض الخلايا كما لوحظ ترسب بروتين الامايلويد بين الخلايا كما ظهر زيادة في الرد الفعل الايجابي لانتشار انزيم النيتريك اوكسايد المستحث و الحمض البروتيني الدبقي الليفي في خلايا التلفيف المسنن التي ظهرت باستخدام الاجسام المضادة لهما ــ ولوحظ في المجموعة المعالجة بالجييسينويد مستخلص عشب الجاردينيا جيسمينويد تحسناً واضحاو نقص في التغير ات بشكل كبير و انحسار في الاختلاف النسيجي عن المجموعة الضابطة الاستنتاج : إن مستخلص عشب الجاردينيا جيسمينويد أحدث تحسنا و اضحا للتغيرات المشابهة لمرض الزهايمر و المستحدثة بالتعرض المزمن للألومنيوم و لهذا ينصح بتناول الجاردينيا جيسمينويد و خاصة لكبار السن و هم الأكثر عرضة لمرض الز هايمر 